\title{
The Future of the College Library
}

President Davidson, of Knox College, Galesburg, Illinois, read this paper at the meeting of the College Libraries Section, June 23, 1942 .

T SUPPOSE I must be an unorthodox adI ministrator, for I assume that when I have a speech to deliver it is the duty of the faculty to help me prepare it-I look to their learning and experience to guide me. Therefore, when I knew this paper was scheduled to be born on June 23, I set the faculty to work to see that it had the proper parentage. On May 8 and 9 we held a symposium on planning for the future of the college library, participated in by six members of the faculty, a student, a trustee, and Dr. McEwen, the librarian of Carleton College. I know the participants profited from preparing their papers; I believe the large audience enjoyed the discussions; I hope the college program will be improved by the suggestions made there; but to me the greatest value of the symposium was that it provided me with the material for this paper. My remarks are, therefore, not wild dreams concocted from my own diseased imagination, but are the sober nightmares of nine other muses.

Perhaps we are foolish to attempt to plan the future of college libraries in 1942; possibly the events of the next few months may change the whole direction of our civilization and, with it, the functions of our colleges and their libraries.
But we must not assume defeat nor anticipate diversion; we must build on our high hopes, not our abject fears.

A college library is, and will continue to be, a collection of books-but it is much more: it is a service bureau for all aspects of college life. As we look at its problems, perhaps the one that looms clearest is a strictly physical one: the housing of this collection in a building. Where will libraries of the future be located and how will they be constructed? The period 1900 to 1940 has been one of immense numerical growth in our book collections-result, the four most important library officials have been the donor who wanted a memorial monumental building, the architect who followed the 1893 World's Fair style or the skyscraper technique of Louis Sullivan, the cataloger who ran up the accession numbers into the hundreds of thousands, and the janitor. I have visited libraries which have expanded the building three or four times by adding wings and floors and tunnelsarchitectural monstrosities and labyrinths of darkness and complexity. But we can't afford to build a new library building every twenty years and our donors won't finance a building to allow for thirty-two times as many books a century from now. What can we do? We can cull, we can weed, we can keep the size of our active book collection at some reasonable figure, say fifty thousand volumes for a student body of five hundred, and we can store 
those of the others we should keep. Burn, bury, sell, or give away the rest. Maybe the students would like some to take home for keepsakes. How is a library book different from an Indian? The only good book is a live book.

Therefore, be satisfied with the size of your building, unless it is woefully inadequate or antiquated. If you are building a new one, don't overbuild in size, but consider especially its location and uses. Near the center of activity-yes! Not out in the woods for quiet, but near the dormitories and classrooms, so the students can't miss it.

The library of 1950 should be built functionally-for use, not external impressiveness. Can you wonder that some students shun its dark fastnesses, when they look upon it and realize that those massive Gothic stone walls were modeled after the medieval crypts and dungeons? Stone walls may not a prison make, nor iron bars a cage-but when you're outside, you try to stay out.

\section{Library Buildings}

For the past forty years librarians have been fighting for buildings of their own, separate from classrooms and faculty offices; for the next forty they will probably be fighting to bring classroom instruction back into the library, through seminar rooms, instruction in the use of the library, the encouragement of honors work in carrels, and the building of faculty offices immediately adjoining the sections of the stacks where books in the appropriate fields are located. The emphasis in the building of the future must be, not on the housing of books, but on the housing of students who are using books; therefore, reading room space for a larger portion of the student body will be sought before more stacks are added for books.

In the past, the library has rarely been considered in the determination of the general program and curriculum of the college; from now on, the librarian should serve as a member of the curriculum committee, helping to plan, and ready to adjust the services of the library to almost every new development in courses or teaching method. Previously, the librarian or his faculty committee has determined what books were to be purchased on the basis of a well-balanced collection; in the future, more study must be given to the purposes of the college and its curriculum, for they will determine the areas for emphasis. Instead of allowing the cataloger to classify books by a mechanical system, it may even be necessary to work out an individualized basis of classification and arrangement to fit the areas of instruction designated by the college.

\section{Effects of War}

Already we are beginning to see the effects of the present war upon our curriculums and therefore on our book purchases-great increases in the fields of physics, aeronautics, military science, geography, and international relations, especially Latin American and Chinese history and economics. A new survey course for freshmen may shift the reading habits of a large part of the student population, so that the librarian must be in on the planning of such courses. Since one of the current well-known curricular experiments advocates the careful reading of one hundred books, the selection of those books is tremendously important to the library of that college. The librarian may well be the instigator of curricular changes, by suggesting library resources which should be better used and by bringing cur- 
ricular literature to the attention of the faculty.

\section{Faculty and Library}

For it is obvious that the faculty members are really the people who build the collection over the years, who determine its uses and its emphases. Therefore, every faculty member should be considered ex officio a member of the library staff, not an intruder, but a cooperator. I prophesy that librarians will be asking that faculty be released from some of their instructional duties in order that they may render reference service to students in bibliography. I know from experience that teaching experience makes better librarians and library service makes better teachers.

Many faculty members will need no urging to make full use of the library; its books they read carefully in the preparation of lectures which cover a much wider field of reading than the student can be expected to study. They cannot afford to buy all these books for themselves, so the library is their friend in need. Sometimes they become too demanding, ask for books obviously tou advanced or limited in scope for college students, demand that the library purchase books for their own research. Unless special funds have been provided for this purpose, college librarians must resist such demands, but offer the facilities of microfilms, interlibrary loans, and catalogs of books available elsewhere.

Those faculty members, often in the sciences and fine arts, who do not seek the library voluntarily, must be lured into the building on every pretext-exhibits, teas, or special invitations. It is true that they have their own laboratories and studies and the library is a laboratory for the social sciences and humanities, but it must, likewise, be made more useful to the fine arts and natural sciences. Books are their heritage as well as test tubes or easels or pianos.

But when we come to the last analysis, we are agreed that it is not faculty but students we wish to serve. I am sometimes disturbed by the nightmare that, for some students, the library is positively immoral in its effects. Most of our students enter with textbook habits: one book to the course and every student has one. Immediately we attempt to pull them out of this adolescent attitude and insist that they find the answers to their questions in the thousands of books in the library. Students are lethargic-they seek short cuts, and, oh, how many short cuts the library provides! Why read the whole of a great literary classic when the library provides neat summaries of its contents? Why work hard to prepare a term paper, when you can probably find one all ready for summarizing, with a bibliography all worked out? Why stand in line and wait your turn on a reserved book when you can probably walk out with the book unnoticed and return it later surreptitiously? Why buy a required textbook if there is one in the library which you can remove from circulation for the duration of the course?

\section{Rules for Students}

In the library of tomorrow something must be done to impress on the student that there is no royal road to learning, that results in the mind are comparable to the efforts expended. Yet the rules set up to prevent dishonesty must not be such as to hamper the sincere student, who, we hope, is in the majority. The library is there to serve, not to preserve. The student who is frustrated in his attempt to 
find what he needs in the library will begin to seek elsewhere or stop looking.

Many colleges work on the assumption that new freshmen already know what a library is for and how it works. But the truth is-they don't. Many have never had to use a library extensively before and others don't know the peculiarities of this library. The chemist doesn't turn his students loose without instruction on the laboratory; he carefully shows them its equipment and where other aids may be found-it is a gradual process, and the student may not feel completely at home in the laboratory for some months; so it must be with the library.

\section{Teaching Unit for Student}

For the student, the library must be a teaching unit, organized to show him how and where to learn what he needs to know. Since most students do much of their studying in the library, the library of tomorrow will try to control his study habits and improve them by providing an atmosphere conducive to study. Since most of that study will be reading, the library must give instruction in how to read: how to skim rapidly or absorb with slow intensity, how to take notes and use the index. The reading room takes the place of the old study hall in preparatory school, with a staff member present to help develop good reading habits. Since some students are dull and others bright, books will be made available for all levels of intelligence and knowledge and prescribed according to needs by an expert. The student will be urged, not to limit himself to the books on reserve, but to browse through the stacks, finding what he needs in unexpected places. Some rooms will be kept quiet for concentrated study, but others will permit the oral dis- cussion so necessary to debate teams or others studying together; still others will be fitted up purely for recreational reading.

\section{Producing Qualities of Mind}

The library must aid in producing the same qualities of mind aimed at by the whole educational program. There is very little the library can do for physical fitness, social grace, or manual dexterity, but its atmosphere and procedure can teach students how to concentrate their attention on the matter under consideration rather than allow their minds to wander while they are supposedly studying. Readers can be taught accuracy in observation and encouraged to develop a retentive memory. If the librarian can also aid in perceptions of relationships, logical reasoning, restrained judgment, and creative imagination, he is leading the student in the paths of mental growth as effectively as any course in the regular classroom instruction.

To carry out so ambitious a program, obviously a well-trained library staff of a size comparable to the student body will be needed. This may seem to some of you unorthodox, but to me the staff functions seem to fall into four categories: direction of studies, personnel, cataloging, and clerical work. For the first task the librarian is obviously needed, and he must be a person who, in training and scholarly accomplishment, need not yield to any other member of the teaching faculty; the doctor's degree for librarians will in the future be as commonplace as it is among chemists. Personnel relations with students and faculty, both for reference work and the circulation of books, will require both knowledge and a pleasant approach, with an ability to supervise student assistants. The cataloger's task will involve 
more withdrawals of books and more modifications of arrangements to suit a flexible curriculum. The clerical functions will probably not require special library training.

One of the great sources of support for libraries in the future will come from alumni, organized into such groups as the Friends of the Knox College Library, which Edward Caldwell, of New York City, has developed in the past ten years into a vital part of our whole library structure, spiritually and financially.

\section{Relations with Administration}

Perhaps I should say a last word about future relations of the college administration to the library. It is safe to say the trustees and executive officers have always been concerned-the history of Knox shows that back in 1853 , when the total educational budget of the college was only $\$ 4350$, the trustees appropriated $\$ 500$ for library expansion. The library of the future has a right to expect continued support from the administration, but it must be remembered that every department must be judged by the results it produces, and if the library uses its plant carelessly, fails to adjust itself to the changing curriculum, discourages faculty members, or hampers the educational development of the students, it is on the spot.

But today, in 1942 , the library on the average college campus is not on the spotit is rather on the threshold of great new opportunities, not for physical expansion, but for important educational service.

\section{Government Publishing in Wartime}

\section{(Continued from page 106)}

defense and war publications. However, comprehensive recording as well as selective listing is needed.

Adequate listing is essential not only to efficient distribution but also to the current and future handling and use of documents by librarians, teachers, students, and research workers.

\section{Recommendations}

30. We believe that some agency of the government should issue weekly or biweekly lists of current printed and "processed" publications. This might be accomplished as a new service or might be incorporated in some existing weekly or biweekly government periodical. Provision should also be made for quarterly or semi- annual subject indexes to these lists.

31. We recommend that, pending the inauguration of periodic listing of all government publications, each department or independent agency be encouraged to issue lists of all of its own publications.

32. All publications, including those which are restricted or confidential, should be included in such lists if not contrary to the public interest.

If government publishing is, as we believe, a tool for use in achieving important national objectives, it is worth the effort now being made to develop a positive policy and program for the employment of that tool for the best possible results. 